\title{
Financial Performance of Brio Bliss for Chennai
}

\author{
Magdalene Peter, S. Fabiyola Kavitha, R. Ramamoorthy
}

\begin{abstract}
Money related investigation of any association is done through examination of its budget report. Budget summary gives important data of past execution and present position of the organization and is considered as 'blue print of the organization'.

In this investigation, a genuine endeavor has been made to break down the money related position of Brio Bliss. Utilizing distinctive budgetary evaluation system like Ratio investigation; Common size asset report examination and so forth., the period secured by this investigation is from 2013 to 2017. The information for the investigation is gotten from distributed yearly report of the organization. An exertion has been made to evaluate the by and large monetary execution and proficiency of the board, yet the degree and profundity of concentrate stayed constrained because of restricting elements of time, and assets. Be that as it may, it is normal that the investigation will give valuable data to the better and simpler comprehension of the money related consequence of the organization. [1],[3],[5]

This investigation has been separated into 5 sections. The primary part has been dedicated to presentation and brief profile and last to the synopsis of end and proposal. The subsequent section gives the examination foundation and strategy. Part three talks about the Literature audit on the subject by different creators. Section 4 talks about the investigation of organization's presentation through working capital examination, proportion examination similar and normal size accounting reports of Brio Bliss.
\end{abstract}

\section{Keywords : Performance,Investigation,Analysis}

\section{INTRODUCTION}

As another worldview dependent on appropriate mix of formal educating and real practice, venture in post graduate recognition courses has been acquainted with get a vibe of genuine Business Environment, to conquer any hindrance between hypothesis and practice and to develop legitimate personality and produce truly necessary resolve for example to assist the understudies with identifying their solid and powerless focuses in the accompanying and acknowledging different hierarchical exercises. With the goal that suitable measures can be taken at a most punctual time.

Fiscal summary are arranged fundamentally for basic leadership the data gave in the budget summaries is of tremendous use in settling on choices through examination

Revised Manuscript Received on July 22, 2019.

Magdalene Peter*, Department of MBA, Bharath Institute of Higher Education and Research, Tamilnadu, India. Email: magdalene.bsb@gmail.com

Dr.S.Fabiyola Kavitha*, Department of MBA, Bharath Institute of Higher Education and Research, Tamilnadu, India. Email: fabiyolakavitha@gmail.com

R.Ramamoorthy*, Department of MBA, Bharath Institute of Higher Education and Research, Tamilnadu, India. Email: ramamoorthy0071@gmail.com and elucidation of budget reports. It is "the way toward distinguishing the money related qualities and shortcoming of the firm by appropriately setting up connection between thing of asset report and benefit and misfortune account". This procedure is analyzation, building up relationship and translation there to comprehend the working and budgetary position of a firm is known as the Financial Performance Analysis. Examination of the budget reports gives a point by point record of business activities and their effect on the money related soundness of the worry. [2],[ 4],[6]

The initial step included alludes to the choice of data pertinent to the reason for assessment from the all out data contained in budget reports. The subsequent advance included is the arrangement or gathering of data such a way to concentrate on the critical relationship. The last advance is the understanding, which incorporates reaching inductions and determinations. [7],[9],[11]

Money related Performance Analysis incorporates both examination and understanding. The term examination is utilized to mean the improvement of money related information precise arrangement of information given in budget reports. Translation implies, clarifying the importance and noteworthiness of the information so rearranged. In this way, investigation and translation are intently interlinked. [8],[10], ,[12]

'Monetary Performance Analysis' is a significant translation of 'Fiscal summaries' for 'parties requesting money related data'. There are sure advances, which must be mulled over for Financial Performance Analysis. First recognizable proof of client's motivation, second ID of information source, last choosing the procedures to be utilized for such investigation [13], [15] , [ 17]

In the expressions of John M. Myer - "Money related Performance Analysis is to a great extent an investigation of relationship among the different monetary factors in a business as unveiled by a solitary arrangement of explanations and an investigation of the patterns of these components as appeared in a progression of proclamations". Hence, the Financial Performance Analysis alludes to the arrangement, finding and examination of the information of budget reports with the goal that the benefit, money related position administrative productivity and shortcoming of the business might be revealed. [14],[ 16], [18] 


\section{Financial Performance of Brio Bliss For Chennai}

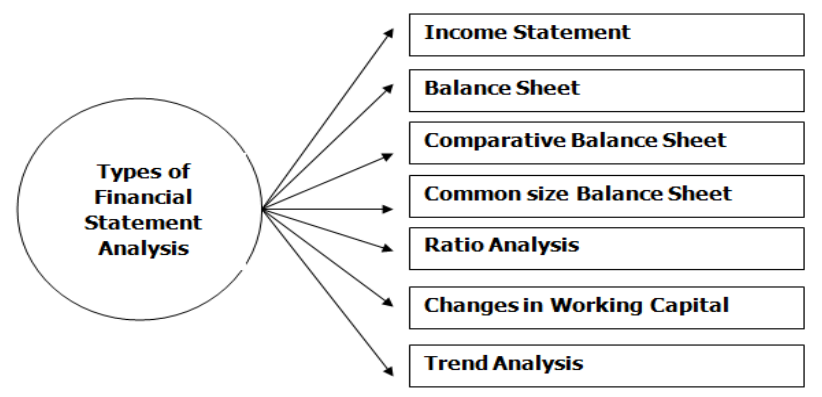

Fig:1

\section{OBJECTIVES}

To assess the money related position through monetary examination of the announcements of Brio Bliss

- To study the money related execution of the organization utilizing different proportions

- To foresee the pattern investigation of specific resources and liabilities

- To think about the presentation through similar asset reports

- To work out normal size proclamations to comprehend the structure of the different resources and liabilities in a critical position sheet, the creation of the different costs and the extent of the benefit (gross, working and net) to Operating Income in the announcement[19],[21],[23]

\section{RESEARCH DESIGN}

The exploration issue having been figured in clear in wording, the examination will be required to set up an examination structure for example research structure for example scientist should express the applied structure with which research would be directed. The Financial proclamations of Brio Bliss have been broke down by the help of near articulation pattern examination explanations, basic size proclamation and by proportion investigation. This investigation is Descriptive in nature. The exploration strategy utilized is diagnostic research. In this sort of research the scientist utilizes the certainties and data officially accessible and breaks down them to make a reproachful of the material. I have picked Qualitative strategy for research for this examination. This technique created gathering and breaking down unstructured data utilizing manual methods. The research is planned in such an approach to focus fundamentally on information gathered through auxiliary mode. [20],[22], [24]

\section{A. Method of Data Collection}

With the end goal of this investigation just optional information have been utilized to a huge degree.

Essential information are the information that are gathered just because and are unique in nature.
The essential information are gathered fundamentally dependent on work force talk with officials in Brio Bliss.

Optional information then again are those that have just been gathered and investigated by another person. Optional information are gathered from distributed records and yearly reports of Brio Bliss. The principle wellspring of information of the examination was the yearly reports of Brio Bliss, web sources, books and articles

\section{B. Sampling Methods}

Information is the recorded proportion of wonder. The accumulation of information should be possible through two different ways. This Project includes just optional information technique. The optional information for this investigation is gathered from the organization's fiscal reports. Because of privacy reasons the organization uncovered just the required data from their books.

\section{Target Company}

This study is made at Brio Bliss, Chennai. This project involves only collection of secondary data

\section{Study Period}

A reference period of 5 years has been taken for the performance analysis i.e. 2015, 2016, 2017, 2016 and 2017

\section{E. Financial tools for data analysis}

1. Ratio Analysis

2. Changes in Working capital

3. Common size Balance sheet

4. Comparative Balance Sheet

5. Trend Analysis

\section{DATA ANALYSIS AND INTERPRETATION}

\section{Working Capital Analysis}

Table 1 The Changes In Working Capital Fy 2016-2017

\begin{tabular}{|l|l|l|l|l|}
\hline Particular & $\mathbf{2 0 1 7}$ & $\mathbf{2 0 1 6}$ & Increase & Decrease \\
\hline Current Asset & & & & \\
\hline Short term Investments & $1,475.70$ & $1,572.98$ & -97.28 & \\
\hline Stock & $1,188.60$ & $1,255.59$ & & 66.99 \\
\hline Debtors & 484.35 & 410.71 & 73.64 & \\
\hline Cash \& bank balance & 91.6 & 304.3 & -212.7 & \\
\hline & $\mathbf{3 , 2 4 0 . 2 5}$ & $\mathbf{3 , 5 4 3 . 5 8}$ & & \\
\hline Current Liabilities & & & & \\
\hline Current liabilities & $3,603.09$ & $3,382.51$ & & 220.58 \\
\hline Provisions & 759.19 & $1,053.21$ & 294.02 & \\
\hline & $\mathbf{4 , 3 6 2 . 2 8}$ & $\mathbf{4 , 4 3 5 . 7 2}$ & & \\
\hline Net Working Capital & $-1,122.03$ & -892.14 & & \\
\hline Decrease in WC & 229.89 & & 229.89 & \\
\hline & -892.14 & -892.14 & 57.68 & 287.57 \\
\hline
\end{tabular}




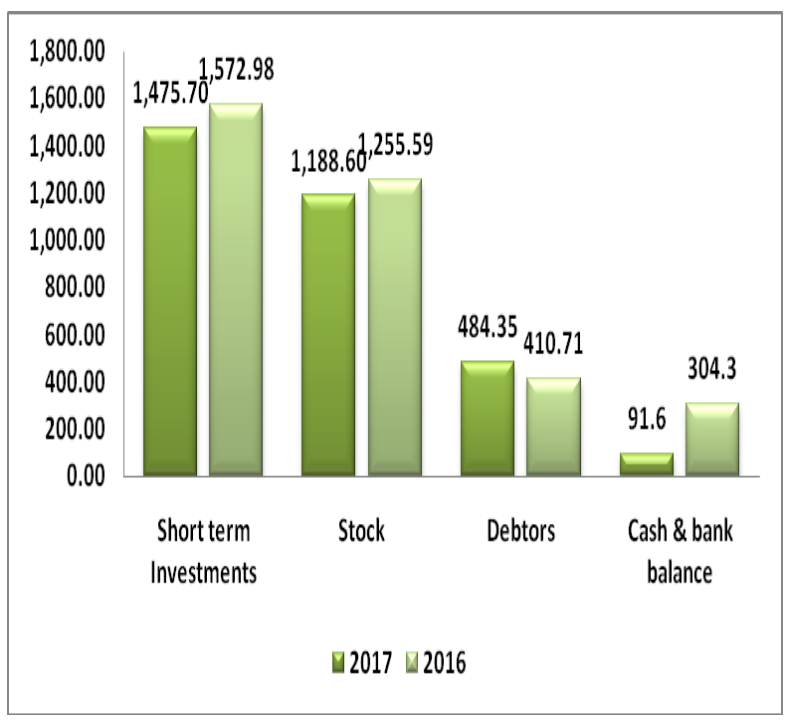

Fig:2 The Variation In Current Assets Fy 2016-2017

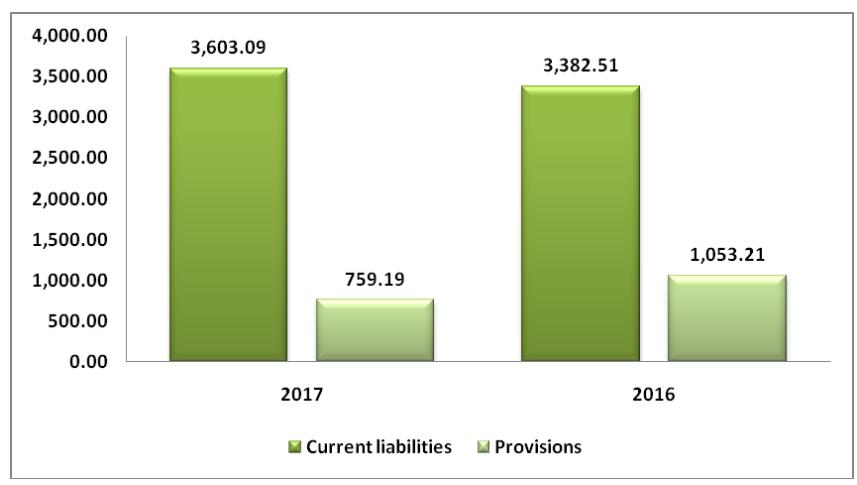

Fig:3 The Variation In Current Liabilities fy 2016-2017

\section{Interpretation:}

The above table demonstrates the working capital proclamation of Brio Bliss for the year 2016 and 2017. Current resources of the organization demonstrate an expanding pattern from the year 2016-2017. Current liabilities expanded from 2016-2017. And still, after all that the Working capital demonstrates an expansion, which gives the organization's great indication of budgetary position. [25],[27],[29]

Table 2 The Changes In Working Capital Fy 2015-2016

\begin{tabular}{|l|l|l|l|l|}
\hline Particular & $\mathbf{2 0 1 6}$ & $\mathbf{2 0 1 5}$ & Increase & Decrease \\
\hline Current Asset & & & & \\
\hline Short term Investments & $1,572.98$ & $2,194.02$ & -621.04 & \\
\hline Stock & $1,255.59$ & $1,121.47$ & & -134.12 \\
\hline Debtors & 410.71 & 397.22 & 13.49 & \\
\hline Cash \& bank balance & 304.3 & 503.38 & -199.1 & \\
\hline & $\mathbf{3 , 5 4 3 . 5 8}$ & $\mathbf{4 , 2 1 6 . 0 9}$ & & \\
\hline Current Liabilities & & & & \\
\hline Current liabilities & $3,382.51$ & $3,098.91$ & & 283.60 \\
\hline Provisions & $1,053.21$ & $1,169.84$ & 116.63 & \\
\hline & $\mathbf{4 , 4 3 5 . 7 2}$ & $\mathbf{4 , 2 6 8 . 7 5}$ & & \\
\hline Net Working Capital & -892.14 & -52.66 & & \\
\hline Decrease in WC & 839.48 & & 839.48 & \\
\hline & -52.66 & -52.66 & -690.00 & 149.48 \\
\hline
\end{tabular}

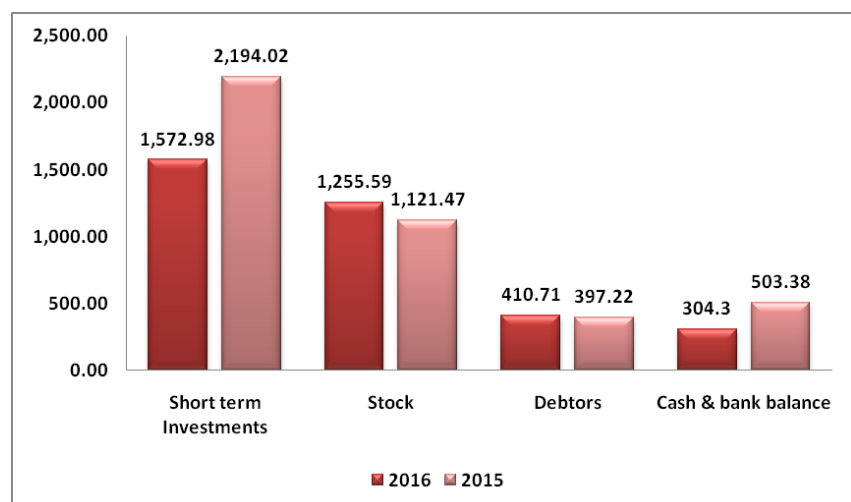

Fig:4 The Variation In Current Assets Fy 2015-2016

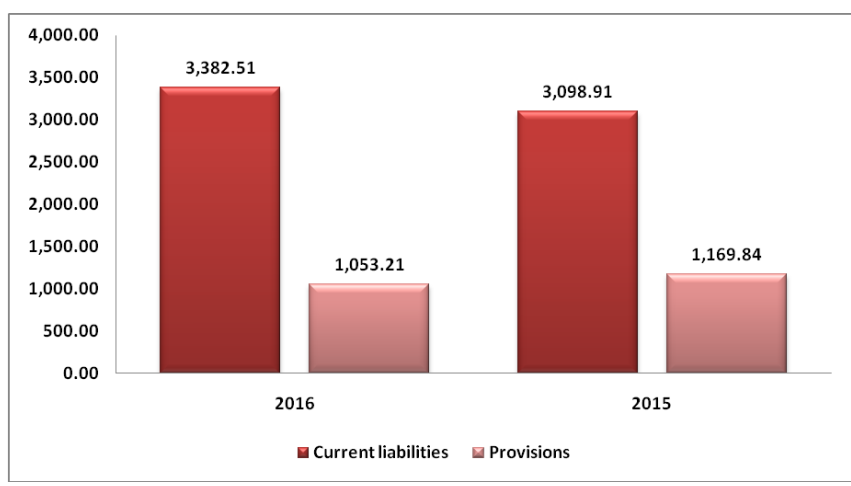

Fig:5 Chart The Variation In Current Liabilitiesfy 2015-2016

\section{Interpretation:}

The above table demonstrates the working capital proclamation of Brio Bliss for the year 2016 and 2017. Current resources of the organization demonstrate an expanding pattern from the year 2016-2017. Current liabilities expanded from 2016-2017. And still, after all that the Working capital demonstrates an expansion, which gives the organization's great indication of budgetary position. $[26],[28],[30]$

Table 3 The Changes In Working Capitalfy 2014-2015

\begin{tabular}{|l|l|l|l|l|}
\hline Particular & $\mathbf{2 0 1 5}$ & $\mathbf{2 0 1 4}$ & Increase & Decrease \\
\hline Current Asset & & & & \\
\hline Short term Investments & $2,194.02$ & $2,553.55$ & -359.53 & \\
\hline Stock & $1,121.47$ & $1,133.55$ & -12.08 & \\
\hline Debtors & 397.22 & 303.45 & 93.77 & \\
\hline Cash \& bank balance & 503.38 & 678.38 & & 175.00 \\
\hline & $\mathbf{4 , 2 1 6 . 0 9}$ & $\mathbf{4 , 6 6 8 . 9 3}$ & & \\
\hline Current Liabilities & & & & \\
\hline Current liabilities & $3,098.91$ & $3,074.31$ & & 24.60 \\
\hline Provisions & $1,169.84$ & $1,384.09$ & & -214.25 \\
\hline & $\mathbf{4 , 2 6 8 . 7 5}$ & $\mathbf{4 , 4 5 8 . 4 0}$ & & \\
\hline Net Working Capital & -52.66 & 210.53 & & \\
\hline Decrease in WC & & -263.19 & & -263.19 \\
\hline & -52.66 & -52.66 & -277.84 & -14.65 \\
\hline
\end{tabular}




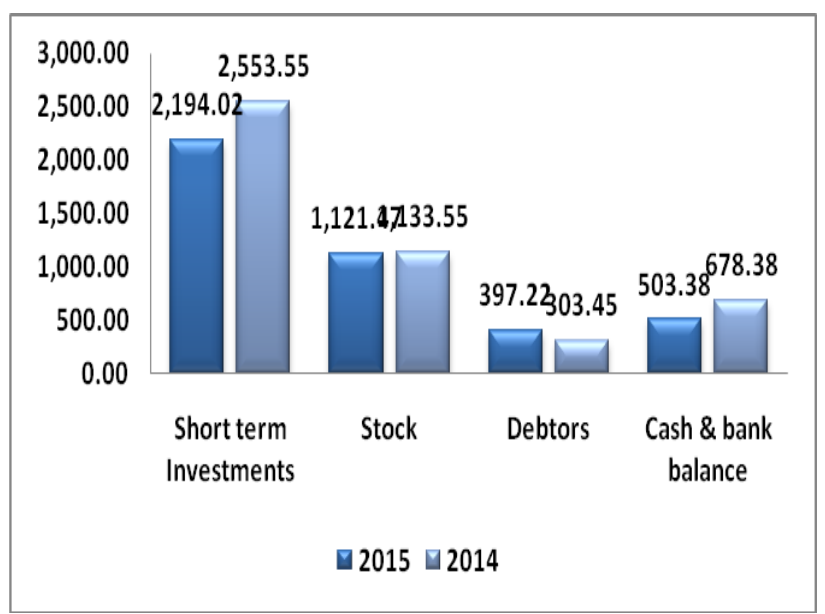

Fig:6 Chart The Variation In Current Assets Fy 2014-2015

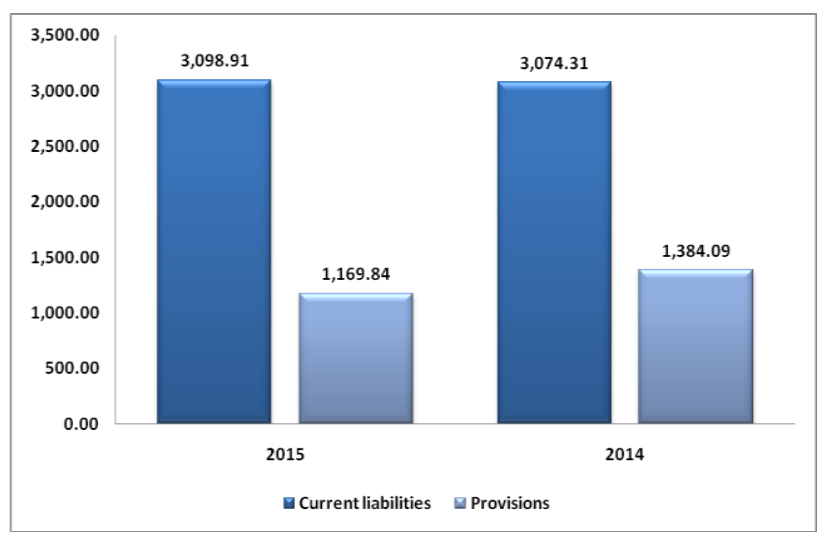

Fig:7 Chart The Variation In Current Liabilities Fy 2014-2015

Interpretation:

The above table shows the working capital statement of Brio Bliss for the year 2014 and 2015. Current assets of the company show an increasing trend from the year 2014-2015. Current liabilities increased from $2014-2015$. This results in a decrease in working capital

Table:4 Showing Inventory Turnover Ratio

\begin{tabular}{|l|l|l|l|}
\hline YEAR & NET SALES & INVENTORIES & $\begin{array}{l}\text { INVENTORY TURNOVER } \\
\text { RATIO }\end{array}$ \\
\hline 2013 & $9,429.62$ & $1,099.54$ & 8.576 \\
\hline 2014 & $11,130.45$ & $1,133.55$ & 9.819 \\
\hline 2015 & $10,908.41$ & $1,121.47$ & 9.727 \\
\hline 2016 & $11,481.05$ & $1,255.59$ & 9.144 \\
\hline 2017 & $11,432.76$ & $1,188.60$ & 9.619 \\
\hline
\end{tabular}

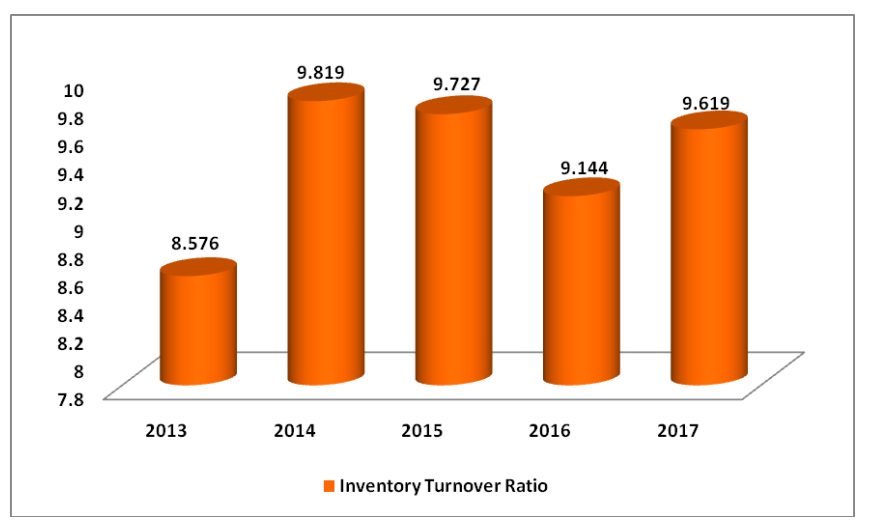

Fig:8 Showing Inventory Turnover Ratio

\section{Interpretation}

In 2013 the inventory turnover ratio of Brio Bliss was 8.58 and it increased to 9.82 in 2014 and thereon started decreasing slowly and reached 9.14 in 2016 and again showed a increasing trend in 2017[31],[33],[32]

FIXED ASSET TURNOVER RATIO

This ratio reveals how efficiently the fixed assets are being utilized.

Table:5 Showing Fixed Asset Turnover Ratio

\begin{tabular}{|l|l|l|l|}
\hline YEAR & NET SALES & $\begin{array}{l}\text { NET FIXED } \\
\text { ASSETS }\end{array}$ & $\begin{array}{l}\text { FIXED ASSET TURNOVER } \\
\text { RATIO }\end{array}$ \\
\hline 2013 & $9,429.62$ & $6,469.49$ & 1.458 \\
\hline 2014 & $11,130.45$ & $7,192.27$ & 1.548 \\
\hline 2015 & $10,908.41$ & $7,382.80$ & 1.478 \\
\hline 2016 & $11,481.05$ & $7,824.84$ & 1.467 \\
\hline 2017 & $11,432.76$ & $8,235.61$ & 1.388 \\
\hline
\end{tabular}

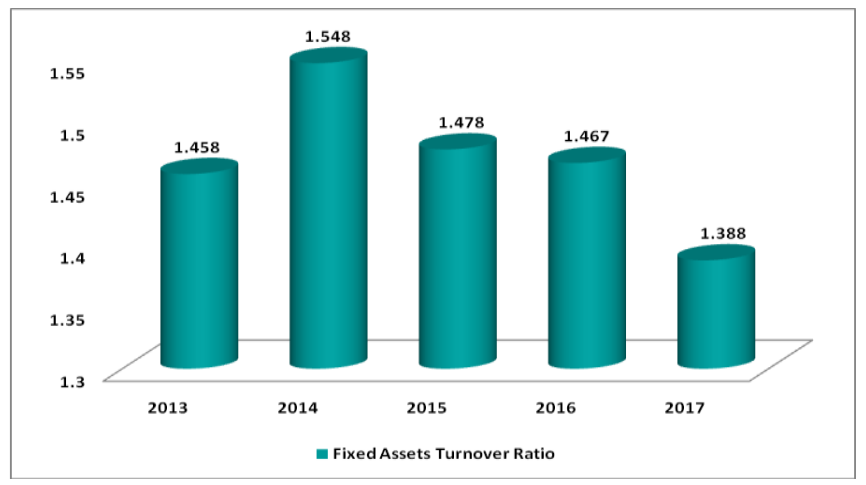

Fig:9 Fixed Asset Turnover Ratio

\section{Interpretation}

In 2013 the fixed assets turnover ratio of Brio Bliss is 1.46 and it increased to 1.55 in 2014 and thereon decreased in the subsequent years and reach 1.39 in 2017

\section{RESULTS AND DISCUSSION}

1.There is a need to control the consumption with respect to the salary.

2 The benefit position of the organization was fluctuating for a long time once it was expanding and used to be diminishing it is to be improved.

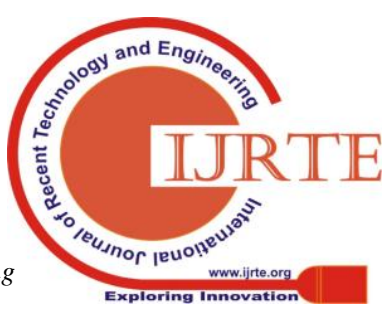


3 If required the organization may differentiate into non-barrier too.

4 The organization should concentrate on improving its working edges as opposed to non-working earnings.

5 The organization should focus on ideal usage of its ability.

6 Promote welfare exercises to raise confidence of the representatives.

7 A centered promoting system/guide must be chalked out to lift up its deals.

\section{CONCLUSION OF THE STUDY}

1. Brio Blissis demonstrating variances in its productivity position from the previous 5 years, which is finished up with the fiscal summary examination.

2. The earlier year resources were additionally expanded yet its working capital position was diminishing which says that the organization was not able meet its present liabilities

3. The count of current proportion and fluid proportion will empower the leasers to get to the present position of the worry in connection to their obligations.

4. Preparation of fiscal reports empowers the Government to see if the association is following different standards and guidelines or not. These announcements give a base to the guideline for the firm.

5. The budget reports are helpful for getting to the productivity for various cost focuses as the administration can exercise cost control through these announcements.

\section{REFERENCES}

1. G BharthVajan R., Ramachandran S.,Psychographic dimensions of training,2016,International Journal of Pharmacy and Technology,V-8,I-4,P-23727-23729

2. Balakrishnan P., Bharthvajan R.,A study on human resource planning in hospitals in Chennai City,2014,International Journal of Applied Engineering Research,V-9,I-22,P-7503-7507

3. Priyadarsini P., Bharthvajan R.,Role of emotional intelligence training programme in reducing the stress of the nurses,2014,International Journal of Applied Engineering Research,V-9,I-22,P-7411-7421

4. Kerinab Beenu G., Bharthvajan R.,Empirical analysis on the cosmetic buying behavior of young women in South India,2014,International Journal of Applied Engineering Research,V-9,I-22,P-7361-7366

5. Balakrishnan P., Bharthvajan R.,Whistling in the wind,2014,International Journal of Applied Engineering Research,V-9,I-22,P-7586-7593

6. Krishnan B., Peter M.,Health hazards of Indian Bpo employee-an alarming issue,2014,International Journal of Applied Engineering Research,V-9,I-22,P-7336-7341

7. Kerinab Beenu G.H., Peter M.,Role of insurance in economic development,2014,International Journal of Applied Engineering Research,V-9,I-22,P-7532-7539
8. Balakrishnan P., Peter M., Priyadarsini P.,Efficiency of safety measures for wellbeing of employees in manufacturing industry,2014,International Journal of Applied Engineering Research,V-9,I-22,P-7376-7382

9. Anbarasi M., Praveen Kumar S.,Online sales promotions of herbal products and its effectiveness towards tanisha.com,2019,Indian Journal of Public Health Research and Development,V-10,I-1,P-195-200

10. Anbarasi M., Praveen Kumar S.,Various online marketing and promotions strategies to improve the validation towards the organic products in the pharmaceutical sectors,2019,Indian Journal of Public Health Research and Development,V-10,I-1,P-263-269

11. Loganathan R., Praveen Kumar S.,Grievance handling a key factor for solving issues of employees in an organization,2014,International Journal of Applied Engineering Research, V-9,I-22,P-7483-7491

12. Loganathan R., Praveen Kumar S.,Study on preference of private label brands in super and Hypermarkets,2014,International Journal of Applied Engineering Research,V-9,I-22,P-7327-7335

13. Smitha M., Praveen Kumar S.,Understanding stress and its managementamong the nurses in Chennai city,2014,International Journal of Applied Engineering Research,V-9,I-22,P-7560-7565

14. Kerinab Beenu G.H., Praveen Kumar S.,A study on the investment behavior of Chennai investors in mutual fund schemes,2014,International Journal of Applied Engineering Research,V-9,I-22,P-7520-7525

15. Loganathan R., Praveen Kumar S.,Retention strategies key for organizational productivity,2014,International Journal of Applied Engineering Research,V-9,I-22,P-7443-7447

16. Pavithra J., Ganesan M., Brindha G.,State wise analysis of microfinance sector in India,2016,International Journal of Pharmacy and Technology,V-8,I-4,P-23417-23432

17. Pavithra J., Ganesan M.,A comparative study on microfinance in India and abroad,2016,International Journal of Applied Business and Economic Research,V-14,I-8,P-5471-5476

18. Pavithra J., Ganesan M.,A study on awareness and impact of micro-financial schemes,2016,International Journal of Applied Business and Economic Research,V-14,I-8,P-5449-5460

19. Senthilmurugan P., Pavithra J.,Consumer preference towards organised retailing with reference to Big Bazaar,2014,International Journal of Applied Engineering Research,V-9,I-22,P-7469-7475

20. Senthilmurugan P., Pavithra J.,Implication of social media marketing in growing healthcare industry,2014,International Journal of Applied Engineering Research,V-9,I-22,P-7448-7456

21. Loganathan R., Pavithra J.,Consumer perception towards private label brand over other brands in super markets and hypermarkets,2014,International Journal of Applied Engineering Research,V-9,I-22,P-7355-7360

22. Kerinab Beenu G., Pavithra J.,Tradeâ€"off between liquidity and profitability in logistics industry,2014,International Journal of Applied Engineering Research,V-9,I-22,P-7398-7401

23. Kerinab Beenu G., Pavithra J.,A study on the prospective consumerâ€ ${ }^{\mathrm{TM}_{\mathrm{S}}}$ perception towards utility cars in Chennai city,2014,International Journal of Applied Engineering Research,V-9,I-22,P-7526-7531

24. Pavithra J., Dilli Babu P., Ambuli T.V.,A study on budgetary control at Maruti Service Masters, Chennai,2014,International Journal of Applied Business and Economic Research,V-12,I-2,P-151-161

25. Pavithra J., Dilli Babu P., Ambuli T.V.,A study on customer satisfaction of retro Garments Pvt Ltd, Chennai,2014,International Journal of Applied Business and Economic Research,V-12,I-2,P-381-391

26. Kerinab Beenu G.H., Pavithra J., Senthilmurugan P.,A study on the influence of promotional activities for TATA ARIA among consumers in Chennai,2014,International Journal of Applied Engineering Research,V-9,I-22,P-7572-7578

27. Vijayaragavan S.P.,An investigative expert that's general FBG sensors,International Journal of Mechanical Engineering and Technology,V-8,I-8,PP-1500-1505,Y-2017

28. Vijayaragavan S.P.,Equalization routing protocol for Wi-Fi sensor strategy,International Journal of Mechanical Engineering and Technology,V-8,I-8,PP-1662-1666,Y-2017

29. Karthik B., Kiran Kumar T.V.U., Vijayaragavan P., Bharath Kumaran E.,Design of a digital PLL using 0.35 $\hat{\mathrm{I}}^{1 / 4 \mathrm{~m}}$ CMOS technology,Middle East Journal of Scientific Research,V-18,I-12,PP-1803-1806,Y-2013

30. Kanniga E., Selvaramarathnam K., Sundararajan M.,Kandigital bike operating system,Middle - East Journal of Scientific Research,V 


\section{Financial Performance of Brio Bliss For Chennai}

31. Jasmin M., Vigneshwaran T., Beulah Hemalatha S.,Design of power aware on chip embedded memory based FSM encoding in FPGA,International Journal of Applied Engineering Research,V-10,I-2,PP-4487-4496,Y-2015

32. Jasmin M.,Optimization techniques for low power VLSI circuits,Middle East Journal of Scientific Research,V-20,I-9,PP-1082-1087,Y-2014

33. Jasmin M., Vigneswaran T.,Fuzzy controller for error control of on - Chip communication,2017 International Conference on Algorithms, Methodology, Models and Applications in Emerging Technologies, ICAMMAET 2017,V-2017-January,I-,PP-1-5,Y-2017

\section{AUTHORS PROFILE}

Magdalene Peter Assistant Professor ,Department of MBA, Bharath Institute of Higher Education and Research, Tamilnadu, India

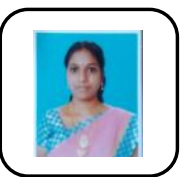

Dr.S.Fabiyola Kavitha Associate Professor ,Department of MBA, Bharath Institute of Higher Education and Research, Tamilnadu, India

R.Ramamoorthy Assistant Professor ,Department of MBA, Bharath Institute of Higher Education and Research, Tamilnadu, India 